Smoking

\section{"Half-pregnant" occupational health policy on environmental tobacco smoke \\ S Chapman}

\section{Comment on the editorial by Edwards et al}

S moking restrictions have been progressively introduced in enclosed public spaces in a growing number of nations as the evidence of the harms of passive smoking accumulates and public preference for smoke free air grows. Bans on smoking on public transport and airlines, and in cinemas, theatres, and elevators have long been taken for granted in many nations. Indoor workplaces are also increasingly becoming smoke free by virtue of either explicit legislation or management policy. Yet throughout the world, hospitality venues-particularly pubs and bars-have staunchly resisted this momentum. The editorial by Edwards et al in this issue ${ }^{1}$ describes a depressingly typical "Groundhog Day" scenario to anyone monitoring global developments in this area.

The situation today is an object lesson in "half-pregnant" policy and in how public health law should not be made. Those least exposed-the relatively transient patrons of restaurants, public transport, cinemas, and shopping malls-have often full legal protection from passive smoking. Yet those most exposed-bar and casino staff-are the least protected. In effect, government inaction says to them "we'll protect citizens from passive smoking even when their exposure is brief. But notwithstanding your unparalleled high exposure, we'll offer you no protection". It is unimaginable that workplace health protection could proceed in such a fashion in relation to toxic fumes, noise, or asbestos.

The neo-Dickensian values inherent in this occupational health practice are being championed by two interest groups whose contempt for the commonly non-unionised casual bar staff's occupational health rights is being driven entirely by the ethics of the cash register. The tobacco industry has a direct financial interest in discrediting the scientific basis for smoking restrictions, and since the 1980s has spent "vast sums of money to keep the controversy alive", ${ }^{2}$ and funded dozens of scientists who were "prepared to do the kinds of things they were recruited to $\mathrm{do}^{\prime \prime 3}$ by trivialising the risks, highlighting alleged confounders, and promoting ventilation as the solution. ${ }^{4}$ Massively funded consultancy programmes designed to attack the science of environmental tobacco smoke have been bank-rolled by the tobacco industry in the USA, ${ }^{5}$ Europe, ${ }^{6}$ Latin America, and Asia. ${ }^{8}$

Why has the tobacco industry been so concerned? As smoking bans proliferate, smoking opportunities continue to erode. Workplace smoking bans cause both smoking cessation and significant reductions in the amount of tobacco consumed by smokers. Workplace smoking bans reduce consumption by up to $29 \%,{ }^{9}$ which translates into hundreds of millions of dollars foregone and reduced smoking unparalleled by any other strategy. Yet bars represent much more than a last ditch stand for the tobacco industry. They are where many graduate from occasional to regular smoking, and are an increasingly exploited venue for sales promotions. A Melbourne study showed that $70 \%$ of regular nightclub and bar patrons report smoking more than normally in these settings, and one in four said they would probably quit if smoking was banned in bars. ${ }^{10}$ Bars are often sentimentalised as the "last bastions" for they are nicotine classrooms where a combination of alcohol and teams of glamorous tobacco company sales staff work to induct and consolidate smoking as an integral part of a good night out. If they lose bars, they lose the last remaining venues for sales promotions in nations where tobacco advertising is banned.

Sections of the hospitality industry have also been prominent in opposing an end to smoking in bars. Their public line is that bans will see customers walk out the door, preferring to drink at home. Industry funding of "fuming bar owner" groups in the USA ${ }^{11}$ has generated a reliable stream of PR-driven anecdotes about the commercial ruination of bars caused by smoking zealotry, but these are not borne out by dozens of studies using before-and-after ban sales smokers. But to the tobacco industry, tax data. ${ }^{12}$ Most telling of all, an internal Philip Morris document states: "the economic arguments often used by the industry to scare off smoking ban activity were no longer working, if indeed they ever did. These arguments simply had no credibility with the public, which isn't surprising when you consider that our dire predictions in the past rarely came true" ${ }^{\prime 13}$

In New South Wales, the death throes of pub smoking have seen truly farcical policies. One memorable advance has been a voluntarily ban on smoking within 2 metres of the bar. The rule embodies the interesting logic that smoke 1.99 metres from bar staff might harm them, but at 2.01 metres, it is benign. And then there was the small problem that everyone forgot to tell the smoke it had to keep back. This is the form that can be expected from industry dominated working parties.

If smoking bans don't stop smokers from going to pubs, and are likely to draw many non-smokers back who have stayed away because of the smoke, how then do we explain the attitude of bar owners opposing bans? In part it is likely to be simple fear of change, predictable through game theory ${ }^{14}$ and mirroring the nervousness of airlines and restaurants which hesitated for years before taking the plunge.

A more complicated answer is that most of the studies about the economic effects of smoking bans have occurred in the USA, where except for Las Vegas, bars do not have gaming machines. The Australian National Institute of Economic and Industry Research has found that smokers spend \$A30.29 per capita per session on gambling compared to \$A13.93 for non-smokers. ${ }^{15}$ Day and night, pub owners observe what a 2003 market research report produced for Victorian Tattersalls concluded, that "Smoking is a powerful re-enforcement for the trance-inducing rituals associated with gambling". ${ }^{15}$ Smoking gamblers can sit for hours at "their" machine, privately convinced that the next press of the button will change their life. In the worst cases, they can urinate in their seats rather than risk taking a break. To force smoking gamblers to take a break to go outside to smoke would break the gambling trance and trigger many to reconsider their gambling. Fresh air might cool gamblers down, prompting many to consider their gambling and tempting players to "go home rather than play on".

A 2000 Melbourne survey done for Philip Morris showed that $51 \%$ of nonsmokers and $44 \%$ of ex-smokers said that they were more likely to go to gambling venues if they were smoke free, while only $2 \%$ of non-smokers and 
$7 \%$ of ex-smokers said they were less likely to attend..$^{15}$ As there are four times as many non-smokers as smokers, a smoking ban may well be revenue neutral.

Smoking bans have not closed restaurants, ${ }^{16}$ affected international travel volume, or caused the end of civilisation as we know it. Tobacco companies oppose smoking bans because they eat away seriously at the number of cigarettes consumed. Their arguments about lost business for others are, by their own internal admissions, absolute nonsense. A hundred years ago, bars had spittoons and often sawdust. While one patron was drinking, another would be spitting. Concerns about expectoration spreading tuberculosis saw spitting relegated to bathrooms. ${ }^{17}$ Unlike the situation with tobacco, there was no spitting industry fulminating about spitters' rights. Historians of public health are likely to view the present period as a shamefully protracted endgame phase in the demise of public smoking.
Occup Environ Med 2004;61:383-384. doi: $10.1136 /$ oem.2004.013615

Correspondence to: Prof. S Chapman, School of Public Health, University of Sydney 2006,

Australia; simonchapman@health.usyd.edu.au

\section{REFERENCES}

1 Edwards PR, van Tongeren M, Watson A, et al. Environmental tobacco smoke. OEM 2004:61:385-6.

2 Chapman S. Tobacco industry memo reveals passive smoking strategy. BMJ 1997;314:1569.

3 Rupp JP, Billings DM. Asia ETS consultant status report. 14 Feb 1990. Philip Morris. Bates No. $2500048976 / 8998$. http:// legacy.library.ucsf.edu/tid/zzd58d00.

4 Drope J, Chapman S. Tobacco industry efforts at discrediting the science of environmental tobacco smoke: a review of internal industry documents. $J$ Epidemiol Community Health 2001;55:588-94.

5 Muggli ME, Hurt RD, Blanke DD. Science for hire: a tobacco industry strategy to influence public opinion on secondhand smoke. Nicotine Tob Res 2003;5:303-14.

6 Nemery B, Piette D. Experts who evaluated studies seem not to have had relevant experience. BMJ 1998;17:348.

7 Barnoya J, Glantz S. Tobacco industry success in preventing regulation of secondhand smoke in Latin America: the "Latin Project". Tob Control 2002;11:305-14.

8 Assunta M, Fields N, Knight J, et al. "Care and feeding": The Asian ETS consultants program.
School of Public Health, University of Sydney. http://tobacco.health.usyd.edu.au/site/ gateway/docs/pdf/Assunta ETS.pdf.

9 Fichtenberg C, Glantz SA. Effect of smoke-free workplaces on smoking behaviour: systematic review. BMJ 2002;325:188-91

10 Trotter L, Wakefield M, Borland R. Socially cued smoking in bars, nightclubs, and gaming venues: a case for introducing smoke-free policies. Tob Control 2002;11:300-4.

11 Dearlove JV, Bialous SA, Glantz SA. Tobacco industry manipulation of the hospitality industry to maintain smoking in public places. Tob Control 2002; 11:94-104.

12 Scollo M, Lal A, Hyland A, et al. Review of the quality of studies on the economic effects of smoke-free policies on the hospitality industry. Tob Control 2003:12:13-20.

13 Walls T. CAC presentation number 4 Tina Walls: Introduction. Philip Morris. Bates No. $2041183751 / 3790$. http://legacy. library.ucsf.edu/tid/vnf77e00 At page 28

14 Shiel A, Chapman S. The inertia of selfregulation: a game-theoretic approach to reducing passive smoking in restaurants. Soc Sci Med 2000:51:1111-19.

15 Harper T. Smoking and gambling: a trance inducing ritual. Tob Control 2003;12:231-3.

16 Weber MD, Bagwell DAS, Fielding JE, et al. Long term compliance with California's Smoke-Free Workplace Law among bars and restaurants in Los Angeles County. Tob Control 2003; 12:269-73.

17 Chapman S. Great expectorations! the decline of public spitting: lessons for passive smoking, BMJ 1995;311:1685-6.

\section{$\mathrm{ECHO}$}

\section{Israeli study uncovers health needs of trafficked female prostitutes}

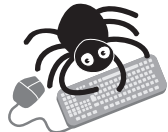

Please visit the Occupational and

Environmental Medicine website [www. occenvmed. com] for a link to the full text of this article. n exploratory study of women working in Israeli brothels, their self reported health
problems, status, and working conditions has policy implications for other countries
where illegal immigrant women are trafficked for prostitution. These disadvantaged

The researchers interviewed 55 volunteers aged 18-38 years working in brothels in Tel Aviv, Beer-Sheva, and Eilat and established baseline detailed demographic and working profiles during a private, questionnaire based, one to one interview.

They found that $82 \%$ of brothel workers in three Israeli cities were illegally trafficked women. Most were working up to 12 hours a day, seven days a week, seeing an estimated 200-300 clients a month-up to twice the number in similar studies. A third had high scores for risk factors such as urinary or sexually transmitted infections likely to increase occupational health risk. Stepwise regression showed age $<18$ at first sexual encounter, suicidal thoughts in the past, hours of work per day, and post-traumatic stress disorder (PTSD) as important variables, and in a final overall regression number of work hours and PTSD were significant predictors of ill health. The few women who were legal immigrantswith access to health care-had slightly better health.

Israel's sex industry is now a high volume business dominated by illegal immigrant women trafficked mainly from the former Soviet Union to work in brothels, where they are more at risk of poor health, violence, and trauma. Understanding their circumstances is crucial to drawing up a healthcare policy for them.

This Echo has also been published in Sexually Transmitted Infections 2004;80:42.

A Journal of Epidemiology and Community Health 2003;57:809-815. 